\title{
Front Matter: Volume 7228
}

, "Front Matter: Volume 7228," Proc. SPIE 7228, Laser Refrigeration of Solids II, 722801 (20 February 2009); doi: 10.1117/12.823973

SPIE Event: SPIE OPTO: Integrated Optoelectronic Devices, 2009, San Jose, SPIE. California, United States 


\title{
PROCEEDINGS OF SPIE
}

\section{Laser Refrigeration of Solids II}

\author{
Richard I. Epstein \\ Mansoor Sheik-Bahae \\ Editors
}

28-29 January 2009

San Jose, California, United States

Sponsored and Published by

SPIE

Volume 7228 
The papers included in this volume were part of the technical conference cited on the cover and title page. Papers were selected and subject to review by the editors and conference program committee. Some conference presentations may not be available for publication. The papers published in these proceedings reflect the work and thoughts of the authors and are published herein as submitted. The publisher is not responsible for the validity of the information or for any outcomes resulting from reliance thereon.

Please use the following format to cite material from this book:

Author(s), "Title of Paper," in Laser Refrigeration of Solids II, edited by Richard I. Epstein, Mansoor Sheik-Bahae, Proceedings of SPIE Vol. 7228 (SPIE, Bellingham, WA, 2009) Article CID Number.

ISSN 0277-786X

ISBN 9780819474742

Published by

SPIE

P.O. Box 10, Bellingham, Washington 98227-0010 USA

Telephone +1 3606763290 (Pacific Time) · Fax +1 3606471445

SPIE.org

Copyright (c) 2009, Society of Photo-Optical Instrumentation Engineers

Copying of material in this book for internal or personal use, or for the internal or personal use of specific clients, beyond the fair use provisions granted by the U.S. Copyright Law is authorized by SPIE subject to payment of copying fees. The Transactional Reporting Service base fee for this volume is $\$ 18.00$ per article (or portion thereof), which should be paid directly to the Copyright Clearance Center (CCC), 222 Rosewood Drive, Danvers, MA 01923. Payment may also be made electronically through CCC Online at copyright.com. Other copying for republication, resale, advertising or promotion, or any form of systematic or multiple reproduction of any material in this book is prohibited except with permission in writing from the publisher. The CCC fee code is 0277-786X/09/\$18.00.

Printed in the United States of America.

Publication of record for individual papers is online in the SPIE Digital Library.

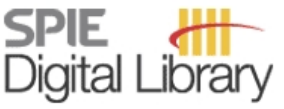

SPIEDigitalLibrary.org

Paper Numbering: Proceedings of SPIE follow an e-First publication model, with papers published first online and then in print and on CD-ROM. Papers are published as they are submitted and meet publication criteria. A unique, consistent, permanent citation identifier (CID) number is assigned to each article at the time of the first publication. Utilization of CIDs allows articles to be fully citable as soon they are published online, and connects the same identifier to all online, print, and electronic versions of the publication. SPIE uses a six-digit CID article numbering system in which:

- The first four digits correspond to the SPIE volume number.

- The last two digits indicate publication order within the volume using a Base 36 numbering system employing both numerals and letters. These two-number sets start with 00, 01, 02, 03, 04 , 05, 06, 07, 08, 09, OA, OB ... 0Z, followed by 10-1Z, 20-2Z, etc.

The CID number appears on each page of the manuscript. The complete citation is used on the first page, and an abbreviated version on subsequent pages. Numbers in the index correspond to the last two digits of the six-digit CID number. 


\section{Contents}

$\checkmark \quad$ Conference Committee

\section{SESSION 1 SEMICONDUCTORS FOR LASER COOLING I}

722803 MBE growth and characterization of semiconductor laser coolers [7228-02]

A. Stintz, C.-Y. Li, M. Sheik-Bahae, K. J. Malloy, The Univ. of New Mexico (United States)

722805 The role of finite spatial beam profiles on photo-luminescence and laser cooling in GaAs structures (Invited Paper) [7228-04]

G. Rupper, N. H. Kwong, R. Binder, College of Optical Sciences, The Univ. of Arizona (United States)

\section{SESSION 2 SEMICONDUCTORS FOR LASER COOLING II}

722807 Anti-Stokes photoluminescence in GaN single crystals and heterostructures (Invited Paper) [7228-06]

S. K. Tripathy, Y. J. Ding, Lehigh Univ. (United States); J. B. Khurgin, Johns Hopkins Univ. (United States)

7228 OB Photoluminescence upconversion in GaAs quantum wells (Invited Paper) [7228-10] S. Eshlaghi, W. Worthoff, Technische Univ. Dortmund (Germany); A. D. Wieck, Ruhr-Univ. Bochum (Germany); D. Suter, Technische Univ. Dortmund (Germany)

\section{SESSION 3 OPTICAL REFRIGERATION IN RARE-EARTH DOPED MATERIALS I}

7228 OC Synthesis and evaluation of ultra-pure rare-earth-doped glass for laser refrigeration (Invited Paper) [7228-1 1]

W. M. Patterson, The Univ. of New Mexico (United States); M. P. Hehlen, Los Alamos National Lab. (United States); M. Sheik-Bahae, The Univ. of New Mexico (United States); R. I. Epstein, Los Alamos National Lab. (United States)

7228 OE Novel materials for laser refrigeration [7228-13]

M. P. Hehlen, Los Alamos National Lab. (United States)

7228 OF Recent progress in laser cooling via resonant cavity [7228-14]

D. V. Seletskiy, S. D. Melgaard, M. P. Hasselbeck, M. Sheik-Bahae, The Univ. of New Mexico (United States); R. I. Epstein, The Univ. of New Mexico (United States) and Los Alamos National Lab. (United States); S. Bigotta, M. Tonelli, Univ. di Pisa (Italy)

\section{SESSION 4 OPTICAL REFRIGERATION IN RARE-EARTH DOPED MATERIALS II}

7228 OG High purity fluoride glass synthesis: a review (Invited Paper) [7228-15]

M. Saad, IRphotonics (Canada) 
$7228 \mathrm{OH}$ Optical characterization and crystal field calculations for some erbium based solid state materials for laser refrigeration (Invited Paper) [7228-16]

Z. Hasan, Z. Qiu, Temple Univ. (United States); J. Johnson, Univ. of Tennessee (United States);

U. Homerick, Hampton Univ. (United States)

7228 ol Rare-earth-doped photonic crystals for the development of solid-state optical cryocoolers (Invited Paper) [7228-17]

A. J. Garcia-Adeva, R. Balda, J. Fernández, Univ. del País Vasco (Spain)

7228 0J Optimization of tapered fiber sample for laser cooling of solids (Invited Paper) [7228-18]

G. Nemova, R. Kashyap, Ecole Polytechnique de Montréal (Canada)

\section{POSTER SESSION}

7228 OK Fast differential luminescence thermometry [7228-19]

D. V. Seletskiy, M. P. Hasselbeck, M. Sheik-Bahae, The Univ. of New Mexico (United States); R. I. Epstein, The Univ. of New Mexico (United States) and Los Alamos National Lab. (United States)

Author Index 


\title{
Conference Committee
}

\author{
Symposium Chair \\ James G. Grote, Air Force Research Laboratory (United States) \\ Symposium Cochair
}

E. Fred Schubert, Rensselaer Polytechnic Institute (United States)

Program Track Chair

Zameer U. Hasan, Temple University (United States)

Conference Chairs

Richard I. Epstein, Los Alamos National Laboratory (United States)

Mansoor Sheik-Bahae, The University of New Mexico (United States)

Program Committee

Rolf H. Binder, College of Optical Sciences, The University of Arizona (United States)

Zameer U. Hasan, Temple University (United States)

Jacob B. Khurgin, Johns Hopkins University (United States)

Yong-Hang Zhang, Arizona State University (United States)

\section{Session Chairs}

1 Semiconductors for Laser Cooling I

Kent L. Miller, Air Force Office of Scientific Research (United States)

2 Semiconductors for Laser Cooling II

Rolf $\mathbf{H}$. Binder, College of Optical Sciences, The University of Arizona (United States)

3 Optical Refrigeration in Rare-Earth Doped Materials I

Zameer U. Hasan, Temple University (United States)

4 Optical Refrigeration in Rare-Earth Doped Materials II

Markus P. Hehlen, Los Alamos National Laboratory (United States) 
Downloaded From: https://www.spiedigitallibrary.org/conference-proceedings-of-spie on 26 Apr 2023

Terms of Use: https://www.spiedigitallibrary.org/terms-of-use 